\title{
Cryosurgery in the treatment of rectal carcinoma
}

\author{
A. L. LAMBRIANIDES \\ B.Sc., F.R.C.S. (Eng, Glasg)
}

\author{
M. W. GHILCHIK
}

B.Sc., M.S., F.R.C.S. (Eng)

St Charles Hospital, Exmoor Street, London W10 6DZ

\begin{abstract}
Summary
Four patients with adenocarcinoma of the rectum were treated by cryosurgery. In all cases there was considerable improvement in local symptomatology following treatment, although in 2 patients troublesome complications were encountered following application of the cryoprobe. All 4 patients are alive at 2 years.

KEY WORDS: rectal carcinoma, cryosurgery.

\section{Introduction}

Cryodestruction for rectal carcinoma can be carried out for those patients who are medically unfit for general anaesthesia or for those who refuse the conventional operative treatment.

The procedure is relatively painless and a general anaesthetic is not necessary. In the anxious patient, intravenous injection of diazepam may be useful.
\end{abstract}

\section{Patients and methods}

All patients came to cryosurgery with the histological diagnosis of well-differentiated adenocarcinoma established (Table 1). Two were unfit for surgery on medical grounds, while the other two refused operative treatment (Table 2). The tumours were frozen using a cryoprobe cooled by nitrous oxide (KRYMED MT 600 , the probe tip being a T2500 maxiderm). The machine produced and maintained temperatures as low as $-70^{\circ} \mathrm{C}$.

The patients were placed in the lithotomy position and a full bimanual pelvic examination was carried out in order to assess size and fixation of the tumour. A Parks anal retractor was introduced into the rectum following anal dilatation. The cryoprobe was initially pressed against the tumour, thermal contact being improved by $\mathrm{K}-\mathrm{Y}$ jelly, and when firm adhesion was achieved, traction was applied to pull the tumour away from surrounding tissues in order to protect underlying structures. The probe was kept in place for $5 \mathrm{~min}$, several applications to different parts of the tumour being necessary.

All patients were seen at 2 monthly intervals for assessment and treatment was given if applicable.

\section{Results}

Complete local tumour regression, as shown by clinical and histological examination, was achieved. in 2 patients after 3 applications of the cryoprobes (Table 3). These patients remained free of locaig disease for a period of 2 months. Troublesome local complications (Table 3 ) in the form of reactionary and secondary haemorrhage requiring blood transfusion, and profuse serous discharge lasting for 2 weeks after application of the cryoprobe were encountered in the other 2. Characteristically, these were theo larger tumours.

There were no deaths, perforations of the bowel $\overrightarrow{0}$ strictures or fistula formation. Local symptomatologyes after treatment was completely eliminated with smaller tumours and considerably improved with thes larger ones.

All 4 patients are alive at 2 years, cases 2 and 4 requiring a total of 8 treatments and cases 1 and 3त् requiring a total of 12 treatments.

\section{Discussion}

The accepted treatment for low rectal carcinoma is abdomino-perineal resection. Circumstances arise however, such as patient refusal or poor genera $E_{-}$. condition, where the least invasive procedure may be necessary to control the problems of the primaryo tumour.

The local management of low rectal carcinoma aso primary treatment has been mainly confined to diathermic fulguration (Madden and Kandalaft, 0 1967; Crile and Turnbull, 1972); local resection. (Parks, 1972) and contact irradiation (Papillon, 1974). Cryosurgery has also been used with goodn results (Langer, 1974). Osborne, Higgins and HobbsN (1978) report good palliation in 6 cases of rectaf carcinoma, although no indication as to the nature size and extent of dimensions is given. Two of theire cases were complicated by the development of rectalo stricture and one by the development of reactionary haemorrhage.

In the present study, the most troublesome compli-市 cation was reactionary and secondary haemorrhage 
TABLE 1. Details of tumour

\begin{tabular}{ccccc}
\hline Case number & Macroscopic appearance & (distance $(\mathrm{cm})$ from anal verge) & Size & Position \\
\hline 1 & Ulcerating & 7 & $4.0 \mathrm{~cm} \times 3.0 \mathrm{~cm}$ & Anterior and lateral rectal wall \\
2 & Ulcerating & 6 & $2.5 \mathrm{~cm} \times 1.0 \mathrm{~cm}$ & $\begin{array}{l}\text { Posterior rectal wall } \\
3\end{array}$ \\
Ulcerating & 6 & $5.0 \mathrm{~cm} \times 2.5 \mathrm{~cm}$ & $\begin{array}{c}\text { Almost involving full } \\
\text { circumference of bowel }\end{array}$ \\
4 & Polypoid & 5 & $2.0 \mathrm{~cm} \times 1.0 \mathrm{~cm}$ & Posterior rectal wall \\
\hline
\end{tabular}

TABLE 2. Details of patients with rectal carcinoma

\begin{tabular}{cccll}
\hline Case number & Age & Sex & \multicolumn{1}{c}{ Symptoms } & \multicolumn{1}{c}{ Problems } \\
\hline 1 & 86 & F & $\begin{array}{l}\text { Rectal bleeding } \\
\text { Change in bowel habit } \\
\text { Rectal bleeding }\end{array}$ & $\begin{array}{l}\text { Refuses surgery } \\
\text { Carcinoma of prostate } \\
\text { Refuses surgery } \\
\text { Chronic obstructive } \\
\text { airways disease } \\
\text { Congestive cardiac failure } \\
\text { Chronic obstructive } \\
\text { airways disease } \\
\text { Congestive cardiac failure }\end{array}$ \\
\hline
\end{tabular}

TABLE 3. Results and complications of treatment

\begin{tabular}{ccll}
\hline Case number & $\begin{array}{c}\text { Number of } \\
\text { treatments }\end{array}$ & \multicolumn{1}{c}{ Results } & \multicolumn{1}{c}{ Complications } \\
\hline 1 & 12 & Tumour bulk regression & Rectal haemorrhage \\
2 & 8 & Complete tumour bulk regression & Nil \\
3 & 12 & Tumour bulk regression & Rectal haemorrhage. Serous discharge \\
4 & 8 & Complete tumour bulk regression & Nil \\
\hline
\end{tabular}

which was severe enough to necessitate blood transfusion, although re-application of the cryoprobe produced haemostasis. This was confined to the larger carcinomas. Small tumours can regress completely on a local basis as shown by clinical and histological examinations. Whether this is only true in the well-differentiated carcinomas treated here is not certain. It is of interest that although larger tumours can have an initial rapid reduction in bulk, further size ablation tended to be extremely slow despite the number of applications of the cryoprobe.

It is our belief that small carcinomas can be locally successfully treated by cryosurgery without complications and with minimal hospital confinement, while the treatment of large tumours tends to be complicated with the resultant morbidity outweighing the benefits.

\section{References}

CRILE, E. Jr. \& TURNBULl, R.B., Jr. (1972) The role of electrocoagulation in the treatment of carcinoma of the rectum. Surgery, Gynecology and Obstetrics, 135, 391.

LANGER, S. (1974) Palliative cryosurgical treatment of the inoperable rectal carcinoma. Minerva Medica, 65, 3643.

MADDEN, J.L. \& KANDALAFT, S. (1967) Electrocoagulation as a primary and preferred method of treatment for cancer of the rectum. Annals of Surgery, 166, 413.

OSBORNE, D.R., HIGGINS, A.F. \& HobBS, K.E.F. (1978) Cryosurgery in the management of rectal tumours. British Journal of Surgery, $65,859$.

PAPILlON, J. (1974) Endocavity irradiation in the curative treatment of early rectal cancers. Diseases of the Colon and Rectum, 17, 182.

PARKS, A.G. (1972) Transanal technique in low rectal anastomosis. Proceedings of the Royal Society of Medicine, 65, 975. 